\title{
PENGARUH TINGKAT PENAMBAHAN DAUN PEPAYA (Carica papaya $L$ ) TERHADAP KARAKTERISTIK NUGGET IKAN LELE
}

\author{
(The Influence of Level Adding Papaya Leaves (Carica papaya $L$ ) to Characteristic of \\ Catfish Nuggets)
}

\author{
Rizki Fadhillah Lubis dan Rahmad Syukur Siregar \\ Fakultas Pertanian Universitas Muhammadiyah Sumatera Utara \\ rizkylubis@umsu.ac.id
}

\begin{abstract}
The purpose of this study was to determine the rate of addition of papaya right to characteristic of catfish nuggets. The design used was completely randomized design (CRD) with 4 treatments and 3 replications. Then do the analysis of variance, followed by Duncan's test New Multiple Range Test (DNMRT) on the real level of 5\%. The treatment used is the addition of papaya leaves ranging from $0 \mathrm{~g}$ (A), $5 \mathrm{~g}$ (B), $10 \mathrm{~g}$ (C) and $15 \mathrm{~g}$ (D) into 100 grams of material. Data were collected for catfish nugget products include: moisture content, ash content, protein content, crude fiber content, fat content, oil absorption power, identification of alkaloids, $\beta$-carotene content, physical analysis, total plate test and organoleptic (color, aroma, taste and texture).

The results showed that the addition of 10 grams of papaya leaves are still acceptable to the percentage of panelists who expressed love to really like the color as much as $95 \%, 85 \%$ aroma, flavor and texture of $65 \%$ to $80 \%$. Chemical analysis of water content obtained $53.37 \%$, ash content $1.41 \%$, $12.22 \%$ protein content; levels of fat before frying $1.88 \%$; levels of fat after frying $9.01 \%, 2.15 \%$ crude fiber; power oil absorption 7.13\%; identification alkaloid $(++)$; $\beta$-carotene content before frying 1993.2201 microg; once fried 1089.0280 microg; violence before frying $3.99 \mathrm{~N} / \mathrm{cm}^{2}$, and after frying $2.71 \mathrm{~N} / \mathrm{cm}^{2}$ and the plates a total of $1.1 \times 104 \mathrm{CFU} / \mathrm{g}$.
\end{abstract}

Keywords: papaya leaves, nugget, catfish, $\beta$-carotene and alkaloids

\section{A. PENDAHULUAN}

Produk pangan instan termasuk nugget yang beredar di pasaran sekarang ini lebih banyak mengandung bahan sumber lemak, garam dan protein serta bahan pengawet kimia, akan tetapi kurang mengandung bahan serat seperti sayur-sayuran sehingga dikhawatirkan akan menimbulkan penyakit dan disfungsi sistem pencernaan.

Sayuran merupakan sumber serat yang utama, antioksidan, vitamin dan mineral yang berfungsi sebagai zat pengatur. Selain itu sayuran mudah diperoleh dengan harga yang relatif murah serta dapat diolah menjadi berbagai macam hidangan. Sayuran berwarna lebih baik daripada sayuran yang tidak berwarna karena warna pada makanan memiliki efek fungsional bagi tubuh. Warna pada makanan memiliki khasiat masing masing dan tergantung dari pigmen yang membentuk warna tersebut, seperti bayam, kangkung, daun singkong, daun pepaya, daun katuk, tomat, kacang panjang, dan sebagainya.

Daun pepaya memiliki total karoten yang cukup tinggi yaitu 18.250 ug (Mahmud, 2009). Menurut Sutama (2008) komponen aktif betakaroten pada daun pepaya mampu menurunkan kolesterol dan sebagai antioksidan, sehingga sangat berpotensi untuk dikembangkan. Di balik rasanya yang pahit, daun pepaya menyimpan manfaat sebagai zat pelawan kanker. Hasil penelitian Sukardiman et al, (2006) menyatakan daun pepaya (Carica papaya L) memiliki aktivitas antikanker terhadap sel mieloma dan mampu menginduksi apoptosis. Berdasarkan hasil analisis kromatogram lapis tipis dan densitometri fraksi kloroform daun pepaya (Carica papaya L.) mengandung senyawa alkaloida. Menurut Duke (1996) cit Sukardiman et al, (2006) kandungan metabolit sekunder dari daun pepaya antara lain adalah senyawa alkaloid karpaina, 
pseudokarpaina yang merupakan alkaloid golongan piperidina. Mengingat rendahnya kandungan serat pada nugget yang ada di pasaran, dibutuhkannya makanan yang praktis, kemudian banyaknya manfaat dan kandungan serta untuk memperpanjang pemanfaatan daun pepaya, maka dapat dilakukan pengolahan yaitu dengan menambahkan daun pepaya terhadap pembuatan nugget.

Ikan merupakan pangan sumber protein dan sumber asam lemak essensial yang sangat penting. Ikan lele (Clarias $s p$ ) merupakan ikan air tawar yang mempunyai prospek cerah, rasa dagingnya enak dan gurih. Hanya saja pemanfaatan ikan lele sekarang masih belum optimal.

Kebutuhan lele konsumsi dalam negeri terus mengalami peningkatan sejalan dengan semakin populernya lele sebagai hidangan yang sangat lezat. Produksi ikan lele di Indonesia beberapa tahun terakhir ini meningkat cukup signifikan dari sekitar 60.000 ton tahun 2004, menjadi 79.000 ton pada tahun 2005 dan terus meningkat hingga 96.140 ton pada tahun 2007 (Irianto dan Soesilo 2007) cit Nurilmala M et al, (2009).

Tujuan penelitian adalah untuk mengetahui tingkat penambahan daun pepaya yang tepat terhadap karakteristik nugget ikan lele.

\section{B. METODOLOGI \\ Bahan dan Alat}

Bahan yang digunakan dalam pembuatan nugget adalah daun papaya dan ikan lele yang segar, tepung tapioka (cap tani), tepung panir, garam dapur, gula pasir, merica, kunyit, jahe, bawang merah, bawang putih, bawang bombay, telur dan minyak goreng.

Bahan kimia yang digunakan untuk analisa kimia yaitu $\mathrm{H}_{2} \mathrm{SO}_{4}$ pekat, $\mathrm{HgO}$, larutan $\mathrm{NaOH}$ dengan $\mathrm{Na}_{2} \mathrm{~S}_{2} \mathrm{O}_{3}$, larutan $\mathrm{H}_{3} \mathrm{BO}_{3}$, larutan $\mathrm{HCl}$, $\mathrm{K}_{2} \mathrm{SO}_{4} 10 \%$, alkohol $95 \%$, batu didih, indikator Metil Merah dan Metil Biru, aquades, garam fisiologis dan PCA.

Peralatan yang digunakan dalam penelitian ini adalah seperangkat analisa protein, analisa lemak, analisa $\beta$-karoten, oven, cawan petri, tanur dan kertas saring.

\section{Rancangan Penelitian}

Rancangan penelitan yang digunakan pada penelitian ini adalah Rancangan Acak Lengkap (RAL) terdiri dari empat perlakuan dan tiga ulangan. Perlakuan yang digunakan adalah penambahan daun pepaya pada pembuatan nugget ikan lele. Keempat perlakuan tersebut adalah:

$\mathrm{A}=$ Penambahan daun papaya $0 \mathrm{gr}$

$\mathrm{B}=$ Penambahan daun papaya $5 \mathrm{gr}$

$\mathrm{C}=$ Penambahan daun papaya $10 \mathrm{gr}$

$\mathrm{D}=$ Penambahan daun papaya $15 \mathrm{gr}$

\section{Pelaksanaan Penelitian \\ Pembuatan Nugget Ikan Lele (Widrial, 2005) yang dimodifikasi}

Ikan lele segar dicuci bersih kemudian difillet. Daun pepaya juga dicuci bersih dan diblansir dengan air panas selama 5 menit. Semua bumbu dibersihkan dan dihaluskan. Fillet lele digiling bersama daun pepaya dan bumbu - bumbu (bawang, garam dapur, gula pasir, merica, kunyit, jahe) sesuai perlakuan kemudian dicampur dengan bahan pengikat (tepung tapioka) dan diaduk sampai homogen. Adonan yang telah homogen dicetak pada loyang dengan ketebalan $1 \mathrm{~cm}$ lalu dikukus selama 10 menit. Setelah itu didinginkan selama 15 menit dan dimasukkan ke dalam freezer ($5^{\circ} \mathrm{C}$ ) selama 2 jam. Adonan dipotong - potong dan dibentuk seragam, lalu dilumuri dengan tepung bumbu dan dicelupkan ke dalam telur kocok, kemudian dilapisi dengan tepung panir. Kemudian dilanjutkan dengan penggorengan hingga nugget berwarna kekuningan dengan menggunakan minyak goreng.

\section{Pengamatan}

Pengamatan yang dilakukan terhadap nugget sebelum digoreng meliputi: kadar air, kadar abu, kadar protein, kadar serat kasar, identifikasi alkaloid, kandungan $\beta$-karoten, uji kekerasan dan uji lempeng total.

Sedangkan pengamatan yang dilakukan terhadap nugget setelah digoreng meliputi: kadar lemak, daya serap minyak, kandungan $\beta$ karoten, uji kekerasan dan organoleptik.

\section{HASIL DAN PEMBAHASAN Kadar Air}

Dari tabel rata - rata kadar air nugget ikan lele yang dihasilkan berkisar antara 56,20 $52,21 \%$. Kadar air tertinggi dihasilkan oleh perlakuan D (penambahan daun pepaya $15 \mathrm{gr}$ ) dengan nilai rata-rata 56,20\%, sedangkan kadar air terendah dihasilkan oleh perlakuan A (tanpa penambahan daun pepaya) dengan nilai ratarata $52,21 \%$. Nilai rata-rata kadar air disajikan pada Tabel 1. 
Tabel 1. Rata-Rata Kadar Air Nugget Ikan Lele

\begin{tabular}{|c|c|c|}
\hline Perlakuan & $\begin{array}{c}\text { Kadar A } \\
(\%)\end{array}$ & Air \\
\hline D. Penambahan daun pepaya $15 \mathrm{gr}$ & 52.21 & $\mathrm{a}$ \\
\hline C. Penambahan daun pepaya $10 \mathrm{gr}$ & 53.37 & $\mathrm{~b}$ \\
\hline B. Penambahan daun pepaya $5 \mathrm{gr}$ & 53.10 & $\mathrm{~b}$ \\
\hline A. Penambahan daun pepaya $0 \mathrm{gr}$ & 56.20 & $\mathrm{~b}$ \\
\hline
\end{tabular}

Berdasarkan uji statistik kadar air nugget ikan lele diketahui bahwa perlakuan $\mathrm{D}$ berbeda nyata dengan perlakuan $\mathrm{A}, \mathrm{B}$ dan $\mathrm{C}$, sedangkan perlakuan $A$, B dan $C$ tidak berbeda nyata satu sama lain. Walaupun demikian, penambahan daun pepaya meningkatkan kadar air nugget karena daun pepaya mengandung kadar air 75,40\%. Menurut standar mutu SNI 01-66832002, yaitu syarat mutu nugget ayam memiliki kadar air maksimal 60\%. Kadar air yang dihasilkan pada nugget ikan lele berkisar antara 52,21 - 54,86\%. Dari hasil yang diperoleh tersebut dapat dikatakan bahwa nilai kadar air nugget ikan lele yang dihasilkan telah memenuhi standar mutu SNI 01-6683-2002.

\section{Kadar Abu}

Berdasarkan uji statistik kadar abu terlihat bahwa tingkat penambahan daun pepaya berpengaruh nyata terhadap kadar abu nugget ikan lele yang dihasilkan. Rata-rata kadar abu yang dihasilkan berkisar antara 1,06 - 1,92\%. Kadar abu tertinggi dihasilkan oleh perlakuan D (penambahan daun pepaya $15 \mathrm{gr}$ ) dengan nilai rata-rata $1,92 \%$. sedangkan kadar abu terendah dihasilkan oleh perlakuan A (tanpa penambahan daun pepaya) dengan nilai ratarata berkisar $1,06 \%$. Nilai rata-rata kadar abu disajikan pada Tabel 2 .

Tabel 2. Rata-Rata Kadar Abu Nugget Ikan Lele

\begin{tabular}{|c|c|}
\hline Perlakuan & $\begin{array}{c}\text { KadarAbu } \\
(\%)\end{array}$ \\
\hline D. Penambahan daun pepaya $15 \mathrm{gr}$ & $1.92 \mathrm{a}$ \\
\hline C. Penambahan daun pepaya $10 \mathrm{gr}$ & 1.41 \\
\hline B. Penambahan daun pepaya $5 \mathrm{gr}$ & 1.37 \\
\hline A. Penambahan daun pepaya $0 \mathrm{gr}$ & 1.06 \\
\hline
\end{tabular}

Meningkatnya kadar abu nugget ikan lele disebabkan oleh tingkat pencampuran daun pepaya dimana semakin tinggi penambahan daun pepaya maka kadar abu nugget semakin tinggi. Hal ini dipengaruhi oleh kadar abu yang terdapat pada daun pepaya yaitu 2,7\%. Menurut Winarno (2004), unsur mineral juga dikenal sebagai zat anorganik atau kadar abu. Dalam proses pembakaran, bahan organik terbakar tetapi zat anorganiknya tidak, karena itulah disebut abu. Mineral yang terkandung dalam daun pepaya adalah kalsium, posfor, dan zat besi.

\section{Kadar Protein}

Dari tabel rata - rata kadar protein nugget ikan lele yang dihasilkan berkisar antara 11,16 - 12,60\%. Kadar protein tertinggi dihasilkan oleh perlakuan D (penambahan daun pepaya 15 gr) dengan nilai rata-rata $12,60 \%$, sedangkan kadar protein terendah dihasilkan oleh perlakuan A (tanpa penambahan daun pepaya) dengan nilai rata-rata $11,16 \%$. Nilai rata-rata kadar protein disajikan pada Tabel 3.

Tabel 3. Rata-Rata Protein Nugget Ikan Lele

\begin{tabular}{lc}
\hline \multicolumn{1}{c}{ Perlakuan } & $\begin{array}{c}\text { Protein } \\
(\%)\end{array}$ \\
\hline A. Penambahan daun pepaya $0 \mathrm{gr}$ & 11.16 \\
B. Penambahan daun pepaya $5 \mathrm{gr}$ & 11.86 \\
C. Penambahan daun pepayA 10 gr & 12.22 \\
D. Penambahan daun pepayA 15 gr & 12.60 \\
\hline KK = 8.74\% &
\end{tabular}

Berdasarkan uji statistik kadar protein diketahui bahwa tingkat penambahan daun pepaya yang berbeda tidak berpengaruh nyata terhadap kadar protein nugget ikan lele yang dihasilkan. Hal ini dikarenakan daun pepaya mengandung protein yang lebih rendah dari kandungan protein ikan lele diamana daun pepaya mengandung protein sebesar $8 \%$. Menurut standar mutu SNI 01-6683-2002, yaitu syarat mutu nugget ayam memiliki kadar protein minimal 12\%. Kadar protein yang dihasilkan pada nugget ikan lele berkisar antara 11,16 - 12,60\%, dapat dikatakan bahwa nilai kadar protein nugget pada perlakuan A dan B yang dihasilkan belum memenuhi standar sedangkan nilai kadar protein nugget pada perlakuan C dan D telah memenuhi standar mutu SNI 01-6683-2002.

\section{Kadar Serat Kasar}

Berdasarkan uji statistik kadar serat kasar diketahui bahwa penambahan daun pepaya berpengaruh nyata terhadap kadar serat kasar nugget ikan lele yang dihasilkan. Nilai rata-rata kadar protein disajikan pada Tabel 4.

Tabel 4. Rata-Rata Serat Kasar Nugget Ikan Lele

\begin{tabular}{llll}
\hline Perlakuan & \multicolumn{3}{c}{ SeratKasar (\%) } \\
\hline A. Penambahan daun pepaya & $0 \mathrm{gr}$ & 1.25 & $\mathrm{a}$ \\
B. Penambahan daun pepaya $5 \mathrm{gr}$ & 2.08 & $\mathrm{~b}$ \\
C. Penambahan daun pepaya 10 gr & 2.15 & $\mathrm{~b}$ \\
D. Penambahan daun pepaya 15 gr & 3.30 & $\mathrm{c}$ \\
\hline
\end{tabular}

$\mathrm{KK}=12.90 \%$ 
Kadar serat kasar rata-rata nugget yang dihasilkan berkisar antara 1,25 - 3,30\%. Kadar serat kasar tertinggi dihasilkan oleh perlakuan D (penambahan daun pepaya 15 gr) dengan nilai rata-rata $3,30 \%$, sedangkan kadar serat kasar terendah dihasilkan oleh perlakuan A (tanpa penambahan daun pepaya) dengan nilai rata-rata 1,25\%. Pada tabel dapat dilihat bahwa semakin banyak daun pepaya yang ditambahkan semakin tinggi kadar serat kasar nugget yang dihasilkan. Hal ini disebabkan oleh daun pepaya yang mengandung serat kasar sebesar $2,10 \%$.

\section{Kadar Lemak}

Dari tabel rata - rata kadar lemak nugget ikan lele yang dihasilkan berkisar antara 1,63 2,41\%. Kadar lemak tertinggi dihasilkan oleh perlakuan A (tanpa penambahan daun pepaya) dengan nilai rata-rata berkisar 2,41\%, sedangkan kadar lemak terendah dihasilkan oleh perlakuan D (penambahan daun pepaya 15 gr) dengan nilai rata-rata $1,63 \%$. Sedangkan nugget setelah digoreng kadar lemaknya berkisar antara 7,41 - 10,64\%. Tingginya kadar lemak nugget setelah digoreng dipicu oleh minyak saat penggorengan ataupun saat pentirisan setelah nugget digoreng.

Tabel 5. Rata-Rata Kadar Lemak Nugget

\begin{tabular}{lcc}
\hline Perlakuan & $\begin{array}{c}\text { Sebelum } \\
\text { Digoreng (\%) }\end{array}$ & $\begin{array}{c}\text { Setelah } \\
\text { Digoreng (\%) }\end{array}$ \\
\hline A. 0 gr & $2.41 \mathrm{a}$ & $10.64 \mathrm{a}$ \\
B. 5 gr & $2.27 \mathrm{a}$ & $10.30 \mathrm{a}$ \\
C. 10 gr & $1.88 \mathrm{~b}$ & $9.01 \mathrm{ab}$ \\
D. 15 gr & $1.63 \mathrm{~b}$ & $7.41 \mathrm{~b}$ \\
\hline & KK $=9.80 \%$ & KK $=10.42 \%$ \\
\hline
\end{tabular}

Berdasarkan uji statistik kadar lemak pada nugget diketahui bahwa penambahan daun pepaya berpengaruh nyata terhadap kadar lemak nugget yang dihasilkan. Dimana semakin tinggi tingkat penambahan daun pepaya kadar lemak pada nugget semakin rendah, hal ini disebabkan kandungan lemak daun pepaya lebih rendah dari kandungan lemak ikan lele dimana daun pepaya mengandung lemak $2 \%$. Menurut standar mutu SNI 01-6683-2002, yaitu syarat mutu nugget ayam memiliki kadar lemak maksimal 20\%. Kadar lemak yang dihasilkan pada nugget ikan lele berkisar antara 1,63 $2,41 \%$. Dari hasil yang diperoleh tersebut dapat dikatakan bahwa nilai kadar lemak nugget ikan lele yang dihasilkan telah memenuhi standar mutu SNI 01-6683-2002.

\section{Daya Serap Minyak}

Pengujian daya serap minyak dilakukan untuk menentukan banyaknya minyak yang terserap selama proses penggorengan. Perhitungan daya serap minyak diperoleh dari pengurangan total kadar lemak setelah digoreng dikurang total kadar lemak sebelum digoreng. Nilai rata-rata daya serapan minyak disajikan pada Tabel 6.

Tabel 6. Rata-Rata Daya Serap Minyak Nugget

\begin{tabular}{ll}
\hline \multicolumn{1}{c}{ Perlakuan } & $\begin{array}{c}\text { Serapan } \\
\text { Minyak(\%) }\end{array}$ \\
\hline A. Penambahan daun pepaya $0 \mathrm{gr}$ & $8.23 \mathrm{a}$ \\
B. Penambahan daun pepaya 5 $\mathrm{gr}$ & $8.02 \mathrm{a}$ \\
C. Penambahan daun pepaya 10 gr & $7.13 \mathrm{ab}$ \\
D. Penambahan daun pepaya 15 gr & $5.77 \mathrm{~b}$ \\
\hline KK $=11.87 \%$ &
\end{tabular}

Nilai rata-rata pengujian serapan minyak yang disajikan pada tabel dapat dilihat bahwa daya serap minyak produk nugget ikan lele berebeda nyata secara statistik pada taraf $5 \%$ yang menandakan adanya pengaruh pencampuran daun pepaya yang berbeda terhadap daya serap minyak nugget yang dihasilkan. Selama proses penggorengan berlangsung minyak akan menerima panas, air yang ada dalam nugget akan menguap, kemudian minyak akan masuk pada pori-pori atau ruang kosong yang tadinya diisi oleh air sehingga terjadinya serapan minyak pada nugget tersebut.

\section{Identifikasi Alkaloid}

Identifikasi alkaloid telah dilakukan pada nugget ikan lele dengan penambahan daun papaya. Dari semua perlakuan menunjukan bahwa perlakuan penambahan daun pepaya teridentifikasi mengandung alkaloid. Menurut Kalie (2003), alkaloid yangterdapat pada daun pepaya adalah jenis alkaloid Karpain $\left(\mathrm{C}_{14} \mathrm{H}_{25} \mathrm{NO}_{2}\right)$. Hasil identifikasi alkaloid pada nugget ikan lele dapat terlihat pada Tabel 7 dibawah ini.

Tabel 7. Identifikasi Alkaloid Nugget Ikan Lele

\begin{tabular}{lc}
\hline Perlakuan & Alkaloid \\
\hline A. Penambahan daun pepaya $0 \mathrm{gr}$ & - \\
B. Penambahan daun pepaya $5 \mathrm{gr}$ & + \\
C. Penambahan daun pepaya 10 gr & ++ \\
D. Penambahan daun pepaya 15 gr & +++ \\
\hline $\mathrm{KK}=11.87 \%$ & \\
\hline Ket: $\quad(+)$ memiliki kandungan alkaloid & \\
& $\quad(-)$ tidak memiliki kandungan alkaloid
\end{tabular}

Dari tabel di atas menunjukkan bahwa semakin tinggi tingkat penambahan daun 
pepaya maka semakin tinggi kandungan alkaloid pada nugget ikan lele. Menurut Sukardiman (2006), daun pepaya mengandung senyawa alkaloid dimana senyawa tersebut memiliki aktivitas antikanker yang mana hasil penelitiannya menunjukkan senyawa alkaloid memiliki aktivitas antikanker terhadap sel kanker mieloma dan mampu menginduksi apoptosis.

\section{Analisis Fisik}

Analisis fisik dilakukan pada nugget ikan lele yang meliputi pada uji kekerasan. Untuk melihat perbandingannya dilakukan terhadap nugget sebelum dan setelah digoreng. Nilai ratarata uji kekerasan disajikan pada Tabel 8 .

Tabel 8. Rata-Rata Uji Kekersan Nugget

\begin{tabular}{lcc}
\hline Perlakuan & $\begin{array}{c}\text { Sebelum } \\
\text { Digoreng } \\
\left(\mathrm{N} / \mathrm{cm}^{2}\right)\end{array}$ & $\begin{array}{c}\text { Setelah } \\
\text { Digoreng } \\
\left(\mathrm{N} / \mathrm{cm}^{2}\right)\end{array}$ \\
\hline A. 15 gr & $4.36 \mathrm{a}$ & $2.79 \mathrm{a}$ \\
B. 10 gr & $3.99 \mathrm{~b}$ & $2.71 \mathrm{a}$ \\
C. $5 \mathrm{gr}$ & $3.79 \mathrm{bc}$ & $2.60 \mathrm{ab}$ \\
D. 0 gr & $1.63 \mathrm{c}$ & $2.40 \mathrm{~b}$ \\
\hline & $\mathrm{KK}=3.52 \%$ & $\mathrm{KK}=5.53 \%$
\end{tabular}

Berdasarkan uji statistik diketahui bahwa penambahan daun pepaya berpengaruh nyata terhadap tingkat kekerasan nugget ikan lele yang dihasilkan. Nilai kekerasan rata-rata nugget sebelum digoreng yang dihasilkan berkisar antara 3,69-4,36 N/ $\mathrm{cm}^{2}$. Kekerasan pada nugget sebelum digoreng disebabkan oleh penyimpanan dalam frezzer sebelum dilakukan uji kekerasan. Pada tabel dapat dilihat bahwa semakin banyak daun pepaya yang ditambahkan semakin tinggi nilai kekerasan nugget yang dihasilkan. Hal ini disebabkan oleh tingginya kandungan air pada nugget sehingga dalam keadaan beku nugget akan mengalami peningkatan nilai kekerasan. Selain itu tingginya kandungan serat juga mempengaruhi tingkat kekerasan produk. Menurut Abdillah (2006), penambahan serat pangan pada produk nugget meningkatkan kekerasan produk tersebut.

Sementara itu, kekerasan pada nugget setelah digoreng mengalami penurunan nilai. Dari tabel diatas didapatkan rata-rata kekerasan nugget setelah digoreng berkisar antara 2,40 - 2,79 N/ $\mathrm{cm}^{2}$. Menurut Muchtadi (2010), selama penggorengan air akan menguap dan digantikan oleh minyak panas. Dengan menguapnya air yang terkandung dalam nugget menyebabkan pori-pori nugget menjadi kosong.
Kekosongan inilah yang akan diisi oleh minyak panas sehingga menyebabkan tingkat kekerasan nugget menjadi turun.

\section{Uji Organoleptik}

Uji organoleptik dilakukan untuk mengetahui tingkat penerimaan panelis terhadap nugget ikan lele yang dihasilkan. Uji organoleptik dilakukan oleh 20 orang panelis dengan parameter meliputi warna, aroma, rasa dan tekstur.

\section{Warna}

Dari hasil organoleptik yang dilakukan panelis terhadap 4 jenis sampel untuk tingkat kesukaan pada segi warna, didapat hasil persentase yang tertera pada tabel 9 berikut: Tabel 9. Nilai Persentasi Warna Nugget

\begin{tabular}{lccccccc}
\hline & \multicolumn{6}{c}{ Tingkatan Kesukaan Warna } & \\
\cline { 2 - 6 } Perlakuan & STS & TS & B & S & SS & \\
\hline A. 0 gr & $0 \%$ & $5 \%$ & $10 \%$ & $60 \%$ & $25 \%$ & $85 \%$ \\
B. 5 gr & $0 \%$ & $0 \%$ & $15 \%$ & $70 \%$ & $15 \%$ & $85 \%$ \\
C. 10 gr & $0 \%$ & $0 \%$ & $5 \%$ & $80 \%$ & $15 \%$ & $95 \%$ \\
D. 15 gr & $0 \%$ & $0 \%$ & $5 \%$ & $80 \%$ & $15 \%$ & $95 \%$ \\
\hline
\end{tabular}

Keterangan $:$ STS = sangat tidak suka, $\mathrm{TS}=$ tidak suka $\mathrm{B}=$ biasa, $\mathrm{S}=$ suka, $\mathrm{SS}=$ sangat suka.

Berdasarkan data pada tabel, dapat dilihat bahwa warna kuning keemasan pada nugget relatif dapat diterima oleh panelis, hal ini terlihat dari tingkat penerimaan panelis terhadap warna pada nugget yang dihasilkan berkisar 85 -95\%. Semakin tinggi penambahan daun pepaya persentase tingkat kesukaan terhadap warna nugget cenderung naik. . Hal ini disebabkan warna hijau pada daun pepaya dinilai menarik oleh panelis, karena dalam pelaksanaannya panelis tidak hanya melihat warna dari luar nugget saja akan tetapi juga melihat disisi dalamnya. Warna produk makanan merupakan daya tarik utama sebelum konsumen mengenal dan menyukai sifat-sifat lainnya. Dengan melihat warna, konsumen telah dapat menilai mutu bahan pangan dengan cepat dan mudah (Soekarto,1985).

\section{Aroma}

Dari hasil organoleptik yang dilakukan panelis terhadap 4 jenis sampel untuk tingkat kesukaan pada segi aroma, didapat hasil persentase yang tertera pada tabel 10 berikut ini: 
Tabel 10. Nilai Persentasi Aroma Nugget

\begin{tabular}{lccccccc|}
\hline & \multicolumn{7}{c|}{ Tingkatan Kesukaan Aroma } \\
\cline { 2 - 6 } Perlakuan & STS & TS & B & S & SS & \\
\hline A. & 0 gr & $0 \%$ & $5 \%$ & $5 \%$ & $45 \%$ & $45 \%$ & $90 \%$ \\
B. 5 gr & $0 \%$ & $0 \%$ & $20 \%$ & $70 \%$ & $10 \%$ & $80 \%$ \\
C. 10 gr & $0 \%$ & $0 \%$ & $15 \%$ & $55 \%$ & $30 \%$ & $85 \%$ \\
D. 15 gr & $0 \%$ & $10 \%$ & $10 \%$ & $70 \%$ & $10 \%$ & $80 \%$ \\
\hline
\end{tabular}

Keterangan : STS = sangat tidak suka, $\mathrm{TS}=$ tidak suka $\mathrm{B}=$ biasa, $\mathrm{S}=$ suka, $\mathrm{SS}=$ sangat suka

Menurut Winarno (2004), bau makanan banyak menentukan kelezatan makanan serta citarasa bahan pangan itu sendiri. Hal yang mempengaruhi citarasa bahan pangan adalah terdiri dari tiga komponen yaitu bau, rasa, dan rangsangan mulut. Berdasarkan data pada tabel, dapat dilihat bahwa aroma pada nugget yang dihasilkan relatif dapat diterima oleh panelis, hal ini terlihat dari tingkat penerimaan panelis terhadap warna pada nugget ikan lele yang dihasilkan berkisar $80-90 \%$.

Aroma nugget yang dihasilkan berasal dari ikan, bahan pengikat, dan bumbu yang digunakan. Selain itu, aroma nugget ikan lele juga diduga dipengaruhi oleh reaksi Maillard yang terjadi dalam proses pengolahan nugget, dimana protein akan mengalami reaksi Maillard akibat bereaksi dengan gula pereduksi yang terdapat dalam bahan. Menurut $\mathrm{M}$ deMan (1997) saat reaksi Maillard terjadi disamping mengakibatkan perubahan warna, bahan juga akan mengalami perubahan rasa dan aroma.

\section{Rasa}

Dari hasil organoleptik yang dilakukan panelis terhadap 4 jenis sampel untuk tingkat kesukaan pada segi rasa, didapat hasil persentase yang tertera pada tabel 11 berikut ini:

Tabel 11. Nilai Persentasi Rasa Nugget

\begin{tabular}{|c|c|c|c|c|c|c|}
\hline \multirow{2}{*}{ Perlakuan } & \multicolumn{5}{|c|}{ Tingkatan Kesukaan Rasa } & \multirow{2}{*}{$\mathrm{S}+\mathrm{SS}$} \\
\hline & STS & TS & B & S & SS & \\
\hline A. $0 \mathrm{gr}$ & $0 \%$ & $5 \%$ & $0 \%$ & $70 \%$ & $25 \%$ & $95 \%$ \\
\hline B. $5 \mathrm{gr}$ & $0 \%$ & $5 \%$ & $20 \%$ & $65 \%$ & $10 \%$ & $75 \%$ \\
\hline C. $10 \mathrm{gr}$ & $0 \%$ & $10 \%$ & $25 \%$ & $55 \%$ & $10 \%$ & $65 \%$ \\
\hline D. $15 \mathrm{gr}$ & $10 \%$ & $10 \%$ & $30 \%$ & $25 \%$ & $5 \%$ & $30 \%$ \\
\hline
\end{tabular}

Menurut Winarno (2004), rasa lebih melibatkan panca indera lidah. Penginderaan cecapan dapat dibagi menjadi empat cecapan utama yaitu asin, asam, manis dan pahit. Rasa merupakan faktor yang sangat penting dalam menentukan penerimaan atau penolakan panelis terhadap bahan pangan. Berdasarkan data pada tabel, dapat dilihat bahwa rasa nugget yang dihasilkan pada perlakuan A B dan C relatif diterima sedangkan perlakuan $D$ tidak diterima oleh panelis yang mana tingkat penerimaan panelis terhadap rasa pada nugget ikan lele yang dihasilkan berkisar $30-95 \%$.

Semakin tinggi penambahan daun pepaya semakin rendah tingkat kesukaan panelis terhadap rasa pada produk. Hal ini disebabkan rasa pahit timbul diakibatkan penambahan daun pepaya yang akhirnya mempengaruhi tingkat penerimaan panelis terhadap produk. Menurut Kalie (2003), rasa pahit pada daun pepaya disebabkan karena alkaloid karpain $\left(\mathrm{C}_{14} \mathrm{H}_{25} \mathrm{NO}_{2}\right)$.

\section{Tekstur}

Dari hasil organoleptik yang dilakukan panelis terhadap 4 jenis sampel untuk tingkat kesukaan pada segi tekstur, didapat hasil persentase yang tertera pada tabel 12 berikut ini:

Tabel 12. Nilai Persentasi Tekstur Nugget

\begin{tabular}{lcccccc}
\hline & \multicolumn{6}{c}{ Tingkatan Kesukaan Tekstur } \\
\cline { 2 - 6 } Perlakuan & STS & TS & B & S & SS & \\
\hline A. 0 gr & $0 \%$ & $5 \%$ & $25 \%$ & $55 \%$ & $15 \%$ & $70 \%$ \\
B. 5 gr & $0 \%$ & $0 \%$ & $25 \%$ & $75 \%$ & $0 \%$ & $75 \%$ \\
C. 10 gr & $0 \%$ & $0 \%$ & $20 \%$ & $60 \%$ & $20 \%$ & $80 \%$ \\
D. 15 gr & $0 \%$ & $0 \%$ & $25 \%$ & $70 \%$ & $5 \%$ & $80 \%$ \\
\hline
\end{tabular}

Keterangan : STS = sangat tidak suka, $\mathrm{TS}=$ tidak suka

$\mathrm{B}=$ biasa, $\mathrm{S}=$ suka, $\mathrm{SS}=$ sangat suka

Penginderaan tentang tekstur biasanya berasal dari sentuhan yang dapat ditangkap oleh seluruh permukaan kulit (ujung jari tangan). Rangsangan sentuhan dapat dari bermacam-macam rangsangan mekanik, fisik dan kimiawi. Dari rangsangan-rangsangan itu dihasilkan kesan rasa rabaan. Kesan itulah yang dapat menggambarkan tekstur suatu produk (Soekarto, 1985). Berdasarkan data pada tabel, dapat dilihat bahwa tekstur pada nugget yang dihasilkan relatif dapat diterima oleh panelis, hal ini terlihat dari tingkat penerimaan panelis terhadap tekstur pada nugget ikan lele yang dihasilkan berkisar $70-80 \%$.

Penambahan daun nugget pepaya ke dalam adonan tidak memberi pengaruh terhadap nugget yang dihasilkan karena daun pepaya yang digunakan telah dihaluskan terlebih dahulu. Tekstur suatu bahan pangan tergantung 
pada keadaan fisik bahan tersebut, penilaian terhadap tekstur dapat berupa kekerasan, kerenyahan dan elastisitas. Tekstur pada suatu produk juga dapat dipengaruhi oleh kandungan protein dan lemak pada bahan. Lemak didalam suatu produk akan menyebabkan produk tersebut menjadi renyah (Mariana, 2007 cit Melisa, 2011).Gambar grafik penilaian organoleptik nugget ikan lele dengan penambahan daun pepaya secara keseluruhan ditampilkan pada Gambar 1.

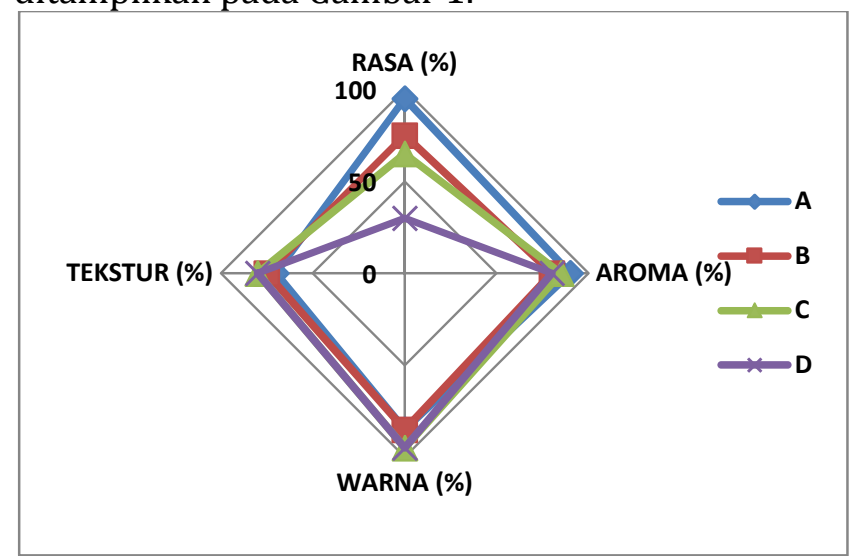

Berdasarkan grafik radar, disimpulkan bahwa penerimaan panelis yang menonjol terhadap nugget ikan lele dengan penambahan daun pepaya terdapat pada perlakuan A yaitu tanpa penambahan daun pepaya. Namun, dikaitkan dari segi sejauh mana peneriman panelis terhadap adanya penambahan daun pepaya ke dalam nugget ikan lele dan dari segi kandungan gizi serta terpenuhinya Standar Nasional Indonesia (SNI) maka perlakuan C (penambahan daun pepaya $10 \mathrm{gr}$ ) menjadi produk terbaik.

\section{Kadar $\beta$-Karoten}

$\beta$-karoten merupakan provitamin A yang terdapat dalam tanaman hijau. Sayuran dan buah yang berwarna hijau atau kuning biasanya banyak mengandung karoten. Ada hubungan langsung antara derajat kehijauan sayuran dengan kadar karoten. Semakin hijau daun tersebut semakin tinggi kadar karotennya, sedang daun-daunan yang pucat seperti selada dan kol miskin akan karoten (Winarno, 2004). Pengujian kadar betakaroten dilakukan pada produk dengan perlakuan terbaik, yaitu perlakuan C (penambahan daun pepaya $10 \mathrm{gr}$ ). Kadar betakaroten pada nugget ikan lele perlakuan C akan disajikan pada Tabel 13.
Tabel 13. Kadar $\beta$-karoten Nugget Produk Terbaik (Perlakuan C)

\begin{tabular}{lll}
\hline No. & Parameter & $\begin{array}{c}\beta \text {-karoten } \\
(\mu \mathrm{g} / 100 \mathrm{gr})\end{array}$ \\
\hline 1. & Sebelum Digoreng & 1993.2201 \\
\hline 2. & Setelah Digoreng & 1089.0280 \\
\hline
\end{tabular}

Dari tabel di atas dapat dilihat bahwa kandungan betakaroten yang terdapat pada nugget ikan lele sebelum dan setelah digoreng berturut-turut adalah sebesar 1.993,2201 $\mu \mathrm{g}$ dan $1.089,0280 \mu \mathrm{g} / 100$ gr bahan. Kandungan betakaroten pada nugget mengalami penurunan ketika setelah digoreng, hal ini disebabkan karena betakaroten (provitamin A) mengalami kerusakan akibat pemanasan. Menurut Winarno (2004), Vitamin A pada umumnya stabil terhadap panas, asam dan alkali. Hanya saja mempunyai sifat yang sangat teroksidasi oleh udara dan akan rusak bila dipanaskan pada suhu tinggi bersama udara, sinar dan lemak yang sudah tengik.

\section{Analisa Mikrobiologi}

Analisa mikrobiologi bertujuan untuk mengetahui tingkat bahaya mikroorganisme yang terdapat dalam bahan pangan. Selain itu, analisa mikrobiologi juga merupakan sebuah indikator sanitasi atau keamanan suatu bahan pangan untuk mengetahui mutu bahan pangan tersebut. Untuk itu pada penelitian ini dilakukan pengujian angka lempeng total terhadap satu produk terbaik menurut hasil organoleptik, yaitu pada perlakuan $\mathrm{C}$ dengan penambahan daun pepaya $10 \mathrm{gr}$.

\section{Pengujian Angka Lempeng Total}

Pengujian lempeng total dilakukan setelah nugget ikan lele disimpan di dalam freezer selama satu bulan. Hasil uji lempeng total nugget ikan lele produk terbaik (perlakuan C) disajikan pada Tabel 14.

Tabel 14. Uji Lempeng Total Nugget Produk Terbaik (Perlakuan C)

\begin{tabular}{cc}
\hline Pengenceran & Angka Lempeng Total (CFU/g) \\
\hline $10^{-2}$ & 113 \\
$10^{-3}$ & 68 \\
$10^{-4}$ & 37 \\
\hline
\end{tabular}

Dari tabel dapat dilihat bahwa terdapat mikroba pada penyimpanan nugget selama satu bulan. Dari hasil yang diperoleh, jumlah total mikroba yang dihasilkan setelah disimpan adalah 1,1 x $10^{4}$. Jika dibandingkan dengan syarat angka lempeng total pada standar SNI nugget ayam maksimal $5 \times 10^{4} \mathrm{CFU} / \mathrm{g}$, maka 
nugget ikan lele dengan penambahan daun pepaya memenuhi syarat.

Penyimpanan nugget ikan lele dilakukan dalam freezer pada suhu $-5^{\circ} \mathrm{C}$. Peningkatan mikroba terjadi karena adanya mikroba psikrofilik yang tumbuh selama penyimpanan. Mikrooorganisme psikrofilik mempunyai kemampuan untuk tumbuh pada suhu $5^{\circ} \mathrm{C}$ sampai $-5^{\circ} \mathrm{C}$ (Buckle, 1987).

\section{KESIMPULAN}

Berdasarkan penelitian yang telah dilakukan dapat diambil beberapa kesimpulan sebagai berikut:

1. Tingkat penambahan daun pepaya memberikan pengaruh dalam peningkatan kadar air, kadar abu, serat kasar dan kekerasan namun penurunan terhadap kadar lemak dan serapan minyak. Namun, tidak berpengaruh terhadap kadar protein.

2. Berdasarkan SNI nugget ayam 01-66832002, nugget ikan lele untuk semua perlakuan (A,B,C dan D) memenuhi standar mutu SNI kecuali kadar protein.

3. Nugget ikan lele dengan penambahan daun pepaya 10 gr didapatkan sebagai produk terbaik, karena memenuhi standar mutu SNI dan dari segi organoleptik juga diterima oleh panelis dengan nilai warna $95 \%$, aroma $85 \%$, rasa $65 \%$, tekstur $80 \%$. Komposisi kimia nugget dengan nilai kadar air 53,37\%, kadar abu 1,41\%, kadar protein $12,22 \%$, kadar lemak sebelum digoreng $1,88 \%$, kadar lemak setelah digoreng $9,01 \%$, serat kasar $2,15 \%$, daya serap minyak 7,13\%, identifikasi alkaloid (++), kandungan $\beta$-karoten sebelum digoreng $1993,2201 \mu \mathrm{g}$ setelah digoreng $1089,0280 \mu \mathrm{g}$, kekerasan sebelum digoreng $3,99 \mathrm{~N} / \mathrm{cm}^{2}$, sesudah digoreng $2,71 \mathrm{~N} / \mathrm{cm}^{2}$ dan lempeng total $1,1 \times 10^{4} \mathrm{CFU} / \mathrm{g}$.

\section{SARAN}

Saran yang diberikan untuk penelitian selanjutnya yaitu menentukan umur simpan nugget dan kemasan yang cocok serta antisipasi rasa pahit yang diakibatkan oleh daun pepaya yang mempengaruhi terhadap nilai organoleptik nugget ikan lele.

\section{DAFTAR PUSTAKA}

Abdillah, F. 2006. Penambahan Tepung Wortel dan Karagenan Untuk Meningkatkan Kadar Serat Pangan Pada Nugget Ikan Nila. [Skripsi] Fakultas Teknologi Pertanian IPB. Bogor.

Buckle, K.A, R.A. Edwards, G.H. Fleet, M. Whotton. 1987. Ilmu Pangan. Universitas Indonesia. Jakarta.

Kalie, 2003. Bertanam Pepaya. Jakarta: Penebar Swadaya

M deMan, John. 1997. Kimia Makanan. Edisi kedua. ITB Bogor.

Mahmud, Mien K, et al. 2009. Tabel Komposisi Pangan Indonesia. Jakarta: Gramedia

Melisa, N. 2011. Pengaruh Pencampuran Tepung Ampas Tahu dan Tepung Terigu Sebagai Bahan Pengikat Terhadap Mutu Nugget Wortel. [Skripsi] Fakultas Teknologi Pertanian UNAND. Padang

Nurilmala M, Nurjanah, Utama RH. 2009. Kemunduran Mutu Ikan Lele Dumbo (Clarias gariepinus) Pada Penyimpanan Suhu chilling Dengan Perlakuan Cara Mati. Jurnal Pengolahan Hasil Perikanan Indonesia 12(1): 1-12.

SNI 01-6683-2002. Syarat Mutu Nuget Ayam. Badan Standardisasi Nasional

Soekarto. 1985. Penilaian Organoleptik Untuk Industri Pangan dan Hasil Pertanian. Jakarta: Bharatara Karya Aksara

Sukardiman, et al, 2006. Aktivitas Antikanker dan Induksi Apoptosis Fraksi Kloroform Daun Pepaya (Carica papaya L) terhadap Kultur Sel Kanker Mieloma. [Jurnal]Media Kedokteran Hewan. Vol. 22, No. 2.

Sutama, I . 2008. Daun Pepaya Dalam Ransum Menurunkan Kolesterol Pada Serum dan Telur Ayam. Jurnal Veteriner Vol. 9 No. 3 : 152-156.

Winarno, F.G, D. 2004. Kimia Pangan dan Gizi. Jakarta: Gramedia. 